\title{
REGULATION OF THE ASYMMETRY IN SPATIAL SOCIAL AND ECONOMIC DEVELOPMENT OF THE WEST KAZAKHSTAN REGION
}

\section{Eduard Imashev ${ }^{1}$}

\begin{abstract}
Based on the research results, the scientific work indicates economic trends and issues in the territorial organization of the economy and population of West Kazakhstan region. Analysis of the spatial development in the economic sphere has shown that there is a territorial localization of the productive forces in the north of West Kazakhstan region. The typology of the West Kazakhstan administrative districts was formed according to their level and pace of socioeconomic and environmental development, from 1997 to 2011, on the basis of rankscoring methodology. The results of this work demonstrate that the Northern administrative districts of West Kazakhstan region have a relatively high or an average level of social and economic development. A low level of social and economic development characterizes the administrative districts located to the south, west, southwest and southeast of West Kazakhstan region. These spatial differences reveal the current asymmetry in the level of social and economic development of the administrative districts, which determined the need for detecting major priorities in regulation of spatial social and economic development of the region. Thus, we propose the basic priorities for the spatial regulation of social and economic development of West Kazakhstan region within the framework of an effective intra-regional policy. The research results can be used by local government agencies to develop a regional management program for spatial social and economic development of West Kazakhstan region.
\end{abstract}

UDC Classification: 553, 332.1’711, DOI: http://dx.doi.org/10.12955/cbup.v2.479

Keywords: West Kazakhstan region, spatial, social, economic development, asymmetry, typology, intra-regional policy, priority

\section{Introduction}

West Kazakhstan region is located in the northwest of the Republic of Kazakhstan. West Kazakhstan region has common borders with Saratov, Samara, and Orenburg regions in the north; with Volgograd and Astrakhan regions of the Russian Federation in the west. Within Kazakhstan it is bordered by Atyrau region in the south and by Aktobe region in the east. The area of the West Kazakhstan region is 151,300 sq. $\mathrm{km}$. At the beginning of 2012, the area population amounted to 612,600 people (DOSWKO, 2012). In its administrative territorial division, West Kazakhstan region consists of 12 administrative districts and the territory of the Uralsk city administration.

The spatial analysis of trends and geo-demographic characteristics, infrastructure, industrial, agricultural, and environmental development of West Kazakhstan region from 1997 to 2011 is evidence of dynamic economic progress (see Table 1) with strengthening of territorial localization of the economy and population.

During 1997 and 2011, localization of the population increased from 63.5\% to 70.3\% in Burlinsky, Zelenovsky, Taskalinsky, Terektinsky districts, in the territory of the Uralsk city administration located in the north, and occupying $20.0 \%$ of West Kazakhstan region. Localization of industrial output in this area rose from $87.1 \%$ to $99.6 \%$; localization of retail trade and paid services rose from $90.5 \%$ to $96.5 \%$; localization of investment in fixed assets rose from $87.9 \%$ to $95.7 \%$; and localization of property assets rose from $91.0 \%$ to $98.5 \%$. Only in agricultural production that the share of the northern districts fell from $74.9 \%$ to $61.2 \%$ (DOSWKO, 2012). Thus, the inertial process of spatial localization of the economy and population in the north of the West Kazakhstan region is in progress and eventuates from territorial differentiation of the available natural resources and raw materials. It is caused by the uneven distribution of production and resettlement of the population, and also by the impact of historical, geographical, economic, and geographical factors.

\footnotetext{
${ }^{1}$ Eduard Imashev, West Kazakhstan State University, Kazakhstan, imashev_edik@mail.ru
} 
CBU I NTERNATIONAL CONFERENCE ON I NNOVATION, TECHNOLOGY TRANSFER AND EDUCATION

February 3-5, 2014, Prague, CZECH Republic

WWW.CBUNI.CZ, OJS.J OURNALS.CZ

\begin{tabular}{|c|c|c|c|c|c|c|}
\hline & 1997 & 2000 & 2003 & 2006 & 2009 & 2011 \\
\hline $\begin{array}{c}\text { Gross regional } \\
\text { product (millions of } \\
\text { U.S. dollars) }\end{array}$ & 0.70 & 0.77 & 1341.97 & 4063.12 & 5583.60 & 9026.99 \\
\hline $\begin{array}{c}\text { Gross regional } \\
\text { product per capita } \\
\text { (U.S. dollars }\end{array}$ & 1.1 & 1.3 & 2228.8 & 6668.5 & 9023.3 & 14839.7 \\
\hline $\begin{array}{c}\text { Industry (millions of } \\
\text { U.S. dollars / \%) }\end{array}$ & $0.08 / 11.4$ & $\begin{array}{r}0.20 / \\
26.0\end{array}$ & $\begin{array}{r}290.33 / \\
21.6\end{array}$ & $\begin{array}{r}1966.34 / \\
48.4\end{array}$ & $\begin{array}{r}2918.70 / \\
52.3\end{array}$ & $\begin{array}{r}4794.06 / \\
53.1\end{array}$ \\
\hline $\begin{array}{c}\text { Agriculture, hunting, } \\
\text { forestry and fishing } \\
\text { (millions of U.S. } \\
\text { dollars / \%) }\end{array}$ & 0.18 / 25.7 & $\begin{array}{r}0.05 / \\
6.5\end{array}$ & $\begin{array}{r}95.37 / \\
7.1\end{array}$ & $\begin{array}{r}139.08 / \\
3.4\end{array}$ & $\begin{array}{r}218.20 / \\
3.9\end{array}$ & $\begin{array}{r}323.87 / \\
3.6\end{array}$ \\
\hline $\begin{array}{c}\text { Construction } \\
\text { (millions of U.S. } \\
\text { dollars / \%) }\end{array}$ & $\begin{array}{r}0.02 / \\
2.9\end{array}$ & $\begin{array}{r}0.17 / \\
22.1\end{array}$ & $\begin{array}{r}187.76 \text { / } \\
14.0\end{array}$ & $\begin{array}{r}374.36 / \\
9.2\end{array}$ & $\begin{array}{r}355.00 / \\
6.4\end{array}$ & $\begin{array}{r}346.71 / \\
3.8\end{array}$ \\
\hline $\begin{array}{c}\text { Transport and } \\
\text { telecommunications } \\
\text { (millions of U.S. } \\
\text { dollars / \%) }\end{array}$ & $0.07 / 10.0$ & $\begin{array}{r}0.10 / \\
13.0\end{array}$ & $\begin{array}{r}148.00 / \\
11.1\end{array}$ & $\begin{array}{r}354.74 / \\
8.7\end{array}$ & $\begin{array}{r}358.90 / \\
6.4\end{array}$ & $\begin{array}{r}570.73 / \\
6.3\end{array}$ \\
\hline $\begin{array}{l}\text { Trade (millions of } \\
\text { U.S. dollars / \%) }\end{array}$ & $0.16 / 22.9$ & $\begin{array}{r}0.06 / \\
7.8\end{array}$ & $\begin{array}{r}138.00 / \\
10.3\end{array}$ & $\begin{array}{r}249.66 / \\
6.2\end{array}$ & $\begin{array}{r}385.00 / \\
6.9\end{array}$ & $\begin{array}{r}464.16 / \\
5.2\end{array}$ \\
\hline $\begin{array}{l}\text { Other services } \\
\text { (millions of U.S. } \\
\text { dollars / \%) }\end{array}$ & 0.19 / 27.1 & $\begin{array}{r}0.19 / \\
24.6\end{array}$ & $\begin{array}{r}482.51 / \\
35.9\end{array}$ & $\begin{array}{r}978.94 / \\
24.1\end{array}$ & $\begin{array}{r}1347.80 / \\
24.1\end{array}$ & $\begin{array}{r}2527.46 / \\
28.0\end{array}$ \\
\hline
\end{tabular}

Source: West Kazakhstan region in the independence years (Anniversary Collection), 2001;

Statistical yearbook of the region, 2004; DOSWKO, 2012).

This polarization in the territorial organization of the economy and population leads to a spatial asymmetry in the level of social and economic development of administrative districts; is a barrier to the formation of the complete territorial socioeconomic system; and reduces the competitiveness of West Kazakhstan region.

Provided that the intra-regional policy is not characterized by accelerated development of the administrative districts in the south, east, west and southwest, the process of "drawing" of workforce and further spatial localization of production capacity, and service industries will be continued by the northern administrative districts. First of all, it will be due to the relatively low social position of the administrative districts in the south, east, west, and southwest. The further development of the economy of the northern administrative districts will be affected by the North axis of Kazakhstan, which is being formed and will pass through the north of West Kazakhstan region.

\section{Materials and research methods}

Information base of the research included scientific literature, periodicals, official websites, regional development programs of West Kazakhstan region, statistical materials of the Department of Statistics and Information of West Kazakhstan region, and data from regional organizations. 
The general scientific and geographic methods, which were used in the research, include: comparative geographic, descriptive, method of typology and ranking, mathematical, analytical, cartographic, and method of statistical analysis.

In order to show the spatial differences in the level of socioeconomic and environmental development, we carried out a typology of the West Kazakhstan region administrative districts. The typology is based on the methods of rank-point assessment of the social and economic development designed by the Ministry of Economic Development of the Russian Federation (Ibragimova, 2006).

This method of estimation consists of 12 benchmarks. In view of the lack of some indicators concerning the West Kazakhstan region administrative districts, such indicators were replaced by other criteria with the addition of the environmental component; as a result, the core indicators increased from 12 to 18 .

The system of core indicators of socio-economic and environmental development includes the following ones:

\section{Economic indicators:}

1. Industrial output per capita (U.S. dollars)

2. Integral component of the main types of agricultural products (grain, potatoes, vegetables, melons, meat, milk, wool) per capita (kg)

3. Investments in fixed capital per capita (U.S. dollars)

4. Total retail sales per capita (U.S. dollars)

5. Volume of services per capita (U.S. dollars)

6. Percentage of employed in small enterprises within the total employment in the economy

7. The book value of fixed assets per capita (U.S. dollars)

8. The density of transport infrastructure (Engel coefficient

\section{Socio-demographic indicators:}

1. Rate of natural population increase (per 1,000 inhabitants)

2. Effectiveness ratio of population migration (\%)

3. Unemployment rate (\%)

4. The percentage of income per capita and subsistence minimum per capita

5. Commissioning of housing (square meters of total area per 1,000 inhabitants)

6. Hospital beds (per 1,000 inhabitants)

7. Availability of public health personnel (number of doctors and nurses per 1,000 inhabitants)

8. Graduates of higher and specialized secondary public schools (per 1,000 inhabitants)

9. Number of recorded crimes (per 1,000 population)

\section{Environmental indicators:}

1. Emissions of air pollutants from stationary sources (density ratio of emissions), the density of transport infrastructure is determined with Engel coefficient (Yudzuro Kato) - $d$ (Dmitrevsky, 1991),

$$
d=\frac{L}{\sqrt{S P}}
$$

where $L$ is the length of transport network $(\mathrm{km}) ; S$ is area $\left(\mathrm{km}^{2}\right) ; P$ is population (people). 
Effectiveness ratio of population migration is defined as follows:

$$
E_{m}=\frac{B}{N_{a}} \times 100 \%
$$

where, $E_{m}$ is effectiveness of population migration; $B$ is balance of migration; $N_{a}$ is number of arrivals (Kozyeva \& Kuzbozhev, 2007).

Density ratio of atmosphere pollutant emissions is calculated according to the following formula:

$$
K_{a t m}=\frac{A}{\sqrt{S \times N}}
$$

where $A$ is atmosphere pollutant emissions; $S$ is land area $\left(\mathrm{km}^{2}\right) ; N$ is an average annual number of population (people) (Zhydkyh, 2003).

Assessment of the socioeconomic and environmental development using the rank-point method is performed in three steps:

1. The rank of each particular administrative district is determined for each of the 18 core indicators starting with the best and ending with the worst value, the rank of average region index value is determined in the same way.

2. Numerical point score $\left(P_{1}^{i}\right)$ is calculated according to each of the indicators for each administrative district as follows:

$$
P_{1}^{i}=\operatorname{Rank}_{1}^{o}-\operatorname{Rank}_{1}^{i}
$$

where $\operatorname{Rank}_{1}^{o}$ is rank of average region value in the total ranking; $\operatorname{Rank}_{1}^{i}$ is rank of the administrative district $i$ in the total ranking.

3. For each administrative district the specified points are added together for all the eighteen accounted core indicators, and then they are divided by 18 :

$$
\text { Complex }_{1}^{i}=\frac{\sum_{i=1}^{18} P_{1}^{i}}{18}
$$

The forecast of population number for the West Kazakhstan region administrative districts is calculated until 2020 using the following formula:

$$
P_{1}=P_{0}+B-D+M_{i}-M_{0}
$$

where $P_{0}$ and $P_{1}$ are the number of population at the beginning and end of the period, respectively; $B$ is the number of births in the period; $D$ is the number of deaths in the period; $M_{i}$ is migration inflow in the period; $M_{0}$ is migration outflow during the period (Safiullina \& Khamadeyeva, 2009).

\section{Typology of the administrative districts according to the West Kazakhstan region socioeconomic and environmental development}

We carried out a typology in order to identify the existing spatial asymmetry in the level of socioeconomic and environmental development of the West Kazakhstan region administrative districts. The typology of the region territory will also allow determining the general directions for effective regulation of the spatial asymmetry of West Kazakhstan region social and economic development. 
The typology shows that the relatively highest level of social and economic development is typical of the territory of the Uralsk city administration and Burlinsky district. At the beginning of 2011, 51.5\% of the region population was present; $95.2 \%$ of industrial and $19.3 \%$ of agriculture production was localized, as well as $90.8 \%$ of turnover of commodities and paid services, along with $96.9 \%$ of property assets, and $69.3 \%$ of the investment in fixed assets. The relatively high rates of economic and social development of the territory of the Uralsk city administration and Burlinsky district are also a consequence of the urbanization effect. Urban life style is typical of these areas (Figure 1).

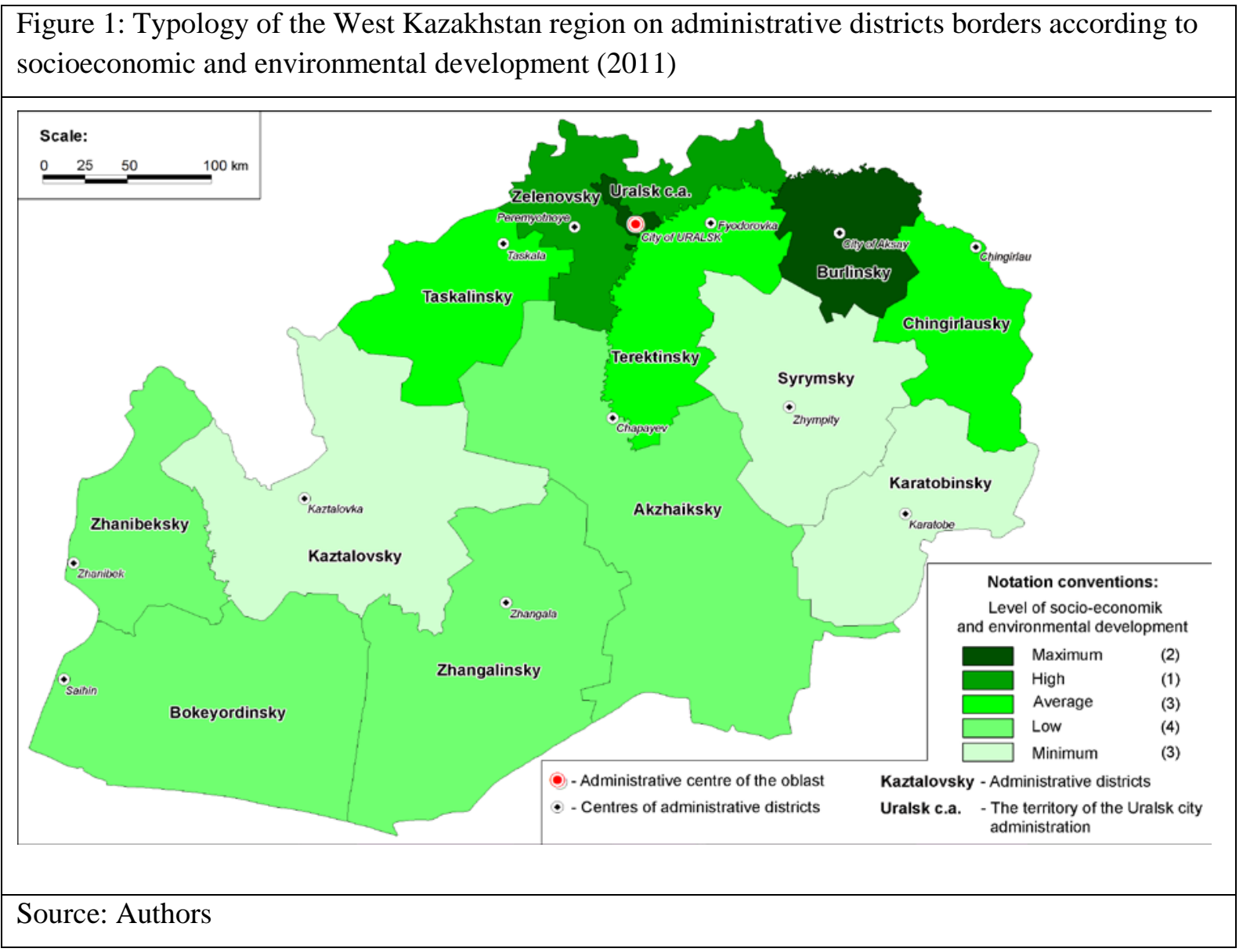

Zelenovsky district has a high level of development, but it is behind the territory of the Uralsk city administration and Burlinsky district according to many indicators. Zelenovski district, in which 9.1\% of the West Kazakhstan region population lived in 2011, is characterized by a high level of agricultural development and is a leader in terms of agricultural production; occupies the third position in industrial production; is ahead of the Uralsk city administration by investment in fixed assets; and is only ranked below Burlinsky district. Zelenovski district had a positive impact on the social sphere. As compared to the administrative districts located in the south, west, southwest, and east (Syrymsky, Karatobinsky districts) of West Kazakhstan region, Terektinsky, Taskalinsky, and Chingirlausky districts have an average level of socioeconomic and environmental development because of existing industrial facilities, transport infrastructure development, agriculture, services, commissioning of housing, etc.

Akzhaiksky, Zhangalinsky, Bokeyordinsky, and Zhanibeksky districts have a low level of development. The minimum economic, social and environmental development is a characteristic of Kaztalovsky, Syrymsky, and Karatobinsky districts.These administrative districts have underdeveloped industry, trade, and services. Extensive and predominant subsistence farming dominates the economy, which determines low competitiveness. There are many problems in the 
social and demographic sphere. The mentioned seven administrative districts have the level of development below the average and are problematic areas that require active measures in the framework of intra-regional policy in West Kazakhstan region.

It is also very important to determine the dynamics and pace of social and economic development of the region administrative districts. The analysis of the dynamics and pace of development according to the system of absolute indicators, used in the rank-point evaluation, showed that all the West Kazakhstan region administrative districts have an overall positive trend from 1997 to 2011. In this case, the positive dynamics of development of administrative districts is characterized with weak stable growth. The pace of growth is also shown in the administrative districts typology presented in Table 2. High rates of development characterize northern administrative districts (except for Taskalinsky district). Akzhaiksky district excels in the south with rate of development above the average region indicator. Eight administrative districts have a lower rate of development than West Kazakhstan region as a whole. Kaztalovsky district, where we estimate the lowest rate, lags behind all the region administrative districts in the pace of development.

Table 2: Typology of the West Kazakhstan region territory on rates and dynamics of development for the period from 1997 to 2011

\begin{tabular}{|c|c|c|c|c|}
\hline & $\begin{array}{c}\text { High rate of } \\
\text { development }\end{array}$ & $\begin{array}{c}\text { Rate of } \\
\text { development } \\
\text { above the } \\
\text { average }\end{array}$ & $\begin{array}{c}\text { Rate of development } \\
\text { below the average }\end{array}$ & $\begin{array}{c}\text { Low rate of } \\
\text { development }\end{array}$ \\
\hline $\begin{array}{c}\text { Positive } \\
\text { dynamics of } \\
\text { development } \\
\text { with low- } \\
\text { grade } \\
\text { sustained } \\
\text { growth }\end{array}$ & $\begin{array}{c}\text { Burlinsky, } \\
\text { Zelenovsky, } \\
\text { districts, the } \\
\text { territory of the } \\
\text { Uralsk city } \\
\text { administration }\end{array}$ & $\begin{array}{c}\text { Akzhaiksky } \\
\text { district }\end{array}$ & $\begin{array}{c}\text { Bokeyordinsky, } \\
\text { Zhangalisky, } \\
\text { Zhanibeksky, } \\
\text { Karatobinsky, } \\
\text { Syrymsky, } \\
\text { Taskalinsky, } \\
\text { Chingirlausky districts }\end{array}$ & $\begin{array}{c}\text { Kaztalovsky } \\
\text { district }\end{array}$ \\
\hline Total & 4 & 1 & 7 & 1 \\
\hline Source: Authors & & & \\
\hline
\end{tabular}

The identified territorial polarization in the organization of economy and population, the typology on level, and pace of socio-economic and environmental development, allow us to determine the general regulation directions of the current asymmetry of the West Kazakhstan region spatial social and economic development.

\section{Priority directions of regulation of spatial social and economic development asymmetry}

The development of market economy, intense competition between regions and territorial social and economic systems, and the current globalization processes require involvement of all the territory in economic activity; all of this could result in higher living standards for the West Kazakhstan region population, which is the end product of the state regional policy. Further territorial polarization in social and economic development of the region may lead to an exacerbation of existing problems, social instability, and reduce the competitiveness of West Kazakhstan region. Intra-regional policy should be directed toward the uniform (balanced) spatial social and economic development of West Kazakhstan region. 
The main objectives and methods of the intra-regional policy, in regulation of spatial social and economic development asymmetry of West Kazakhstan region, should be an arrangement of the best possible conditions for people's life by mobilizing available resources and implementation of untapped potential. Primary direction in the management of the region spatial social and economic development is the solution of socio-demographic issues, which are the main factors in the outflow of population from the administrative districts in the south, west, east, southwest of West Kazakhstan region to the northern administrative regions and outside the region. This will lead to deformation in the territorial organization of economy and population. As a result, these negative processes reduce the efficiency of the integrated region system organization; determine low competitiveness of the West Kazakhstan region economy; and create new social and demographic problems. In addition, further concentration of economy and population in the north of West Kazakhstan region will lead to environmental deterioration, and will act as a limiting factor to further social and economic development of this part of the region.

Let us consider the social and economic problems of the West Kazakhstan region administrative districts identified in the typology. The lowest level of socioeconomic and environmental development is a characteristic of Kaztalovsky, Karatobinsky and Syrymsky districts (Figure 1). According to all analyzed social and demographic indicators (except the rate of natural population movement), these administrative districts have a high negative rate of the population emigration and unemployment. The population has low income, poor health services, and poorly developed training in vocational colleges. These administrative districts are laggard in construction of housing per capita.

The reasons for the low level of social development of Kaztalovsky, Karatobinsky, and Syrymsky districts lie in poorly organized economy, which is not able to fully satisfy even the internal needs of the population, thus having low competitiveness. Industry, trade, and services are underdeveloped in these administrative districts. The main production industry is agriculture. The integral indicator of the main types of agricultural production per capita shows poor provision of residents of Karatobinsky and Kaztalovsky districts with their own agricultural products. The territory of Syrymsky district has a higher level of agricultural development. The three administrative districts also exhibit low attractiveness for investment in fixed capital and weak development of fixed assets. Syrymsky and Karatobinsky areas are characterized by a low density of transport infrastructure.

Akzhaiksky, Bokeyordinsky, Zhangalinsky, and Zhanibeksky districts have similar social and economic problems. Meanwhile, they take the lead over Kaztalovsky, Karatobinsky, Syrymsky districts in terms of development (Figure 1).

Our forecast analysis shows that the number of residents will increase slightly by 2020 due to the relatively high levels of the natural population movement in the five districts (see Table 3). The population of Bokeyordinsky and Zhangalinsky districts will decline. Provided that the positive trends in natural population movement and reducing of the population outflow remain by 2020, the number of residents in the five administrative districts will increase even more. Reducing of emigration of population of Bokeyordinsky and Zhangalisky districts can also reverse the downward trend in population to its increase. In this regard, the local executive bodies of the administrative districts should strengthen their efforts to reduce unemployment, to develop housing and health care, and to provide vocational colleges with necessary educational and technical resources, all with the support of the region's administration incl. region's parliament. The problem of employment of the population should be solved by encouraging development of new competitive industries, for example, based on processing of agricultural raw materials. Support and subsidies for housing, health care, and education can simultaneously solve the problem of unemployment, housing supply, etc. In our opinion, all of these measures can reduce the outflow from these administrative districts and increase the number of residents, enhance economic activities in these areas, and improve the quality of life of the population. 
Under the control of the spatial asymmetry of the West Kazakhstan region social and economic development, it is necessary to accelerate the process of social and economic development of the mentioned administrative districts in the south, east, west, and southwest of the region realizing the intra-regional policy. The methods of regulation by government agencies should further undergo the development of transport, industrial, social and market infrastructure, and the creation of enabling environment for investments both in the industrial and social sectors. The work on development and improvement of rural areas through regional programs should be carried out more actively. Every year, the region's budget shall provide funding and subsidies on a preferential basis to support small and medium-sized enterprises through establishment of branches and representative offices of financial institutions in large rural settlements. It is necessary to inform businesspeople and population about provision of financial assistance, tax remissions, provision of land, and other incentives to create new priority industrial facilities, including a mechanism of public-private partnerships. Business entities engaged in the agricultural sector should be provided with an opportunity to borrow at low interest rates for spring and autumn fieldwork, acquisition and renovation of agricultural machinery, fertilizers, seeds, livestock breeding, and creation of fattening and paddocking base.

In general, priorities should be given to the agro-industrial complex in development of the economy of the administrative districts as they have great potential for agricultural resources requiring mobilization. The realizing policy should create conditions in these administrative districts to attract highly qualified personnel in the field of health, education, and management of public institutions, and to encourage development of human capital, etc.

\begin{tabular}{|c|c|c|c|}
\hline \multirow[t]{2}{*}{ № } & \multirow[t]{2}{*}{ Administrative districts } & \multicolumn{2}{|c|}{$\begin{array}{l}\text { Population number, } \\
\text { thousands of people }\end{array}$} \\
\hline & & 2011 & 2020 (forecast) \\
\hline 1 & Akzhaiksky & 41.5 & 45.9 \\
\hline 2 & Bokeyordinsky & 16.5 & 17.6 \\
\hline 3 & Burlinsky & 54.1 & 56.0 \\
\hline 4 & Zhangalinsky & 23.6 & 22.6 \\
\hline 5 & Zhanibeksky & 16.7 & 19.1 \\
\hline 6 & Zelenovsky & 55.1 & 54.7 \\
\hline 7 & Kaztalovsky & 32.2 & 36.3 \\
\hline 8 & Karatobinsky & 16.7 & 20.7 \\
\hline 9 & Syrymsky & 21.1 & 27.1 \\
\hline 10 & Taskalinsky & 17.1 & 19.1 \\
\hline 11 & Terektinsky & 38.9 & 40.3 \\
\hline 12 & Chingirlausky & 15.8 & 22.5 \\
\hline \multirow[t]{2}{*}{13} & Uralsk c. a. & 259.0 & 257.6 \\
\hline & West Kazakhstan region & 608.3 & 639.5 \\
\hline
\end{tabular}

In view of the spatial asymmetry in the level of social and economic development of administrative districts, there is a need to conduct territorial and structural transformation and modernization of the West Kazakhstan region economy to form a single competitive territorial social and economic system, which is able to improve the quality of life, both in the cities and in the rural areas. Figure 2 shows 
primary directions of territorial and structural transformation and modernization of the West Kazakhstan region economy, which can help to reduce the spatial concentration of productive forces, the spatial asymmetry in the level of social and economic development of the administrative districts, and to improve competitiveness of the economy and efficiency of the territorial organization of the West Kazakhstan region economy and population.

Figure 2: Priority directions of territorial and structural transformation and modernization of the West Kazakhstan region economy

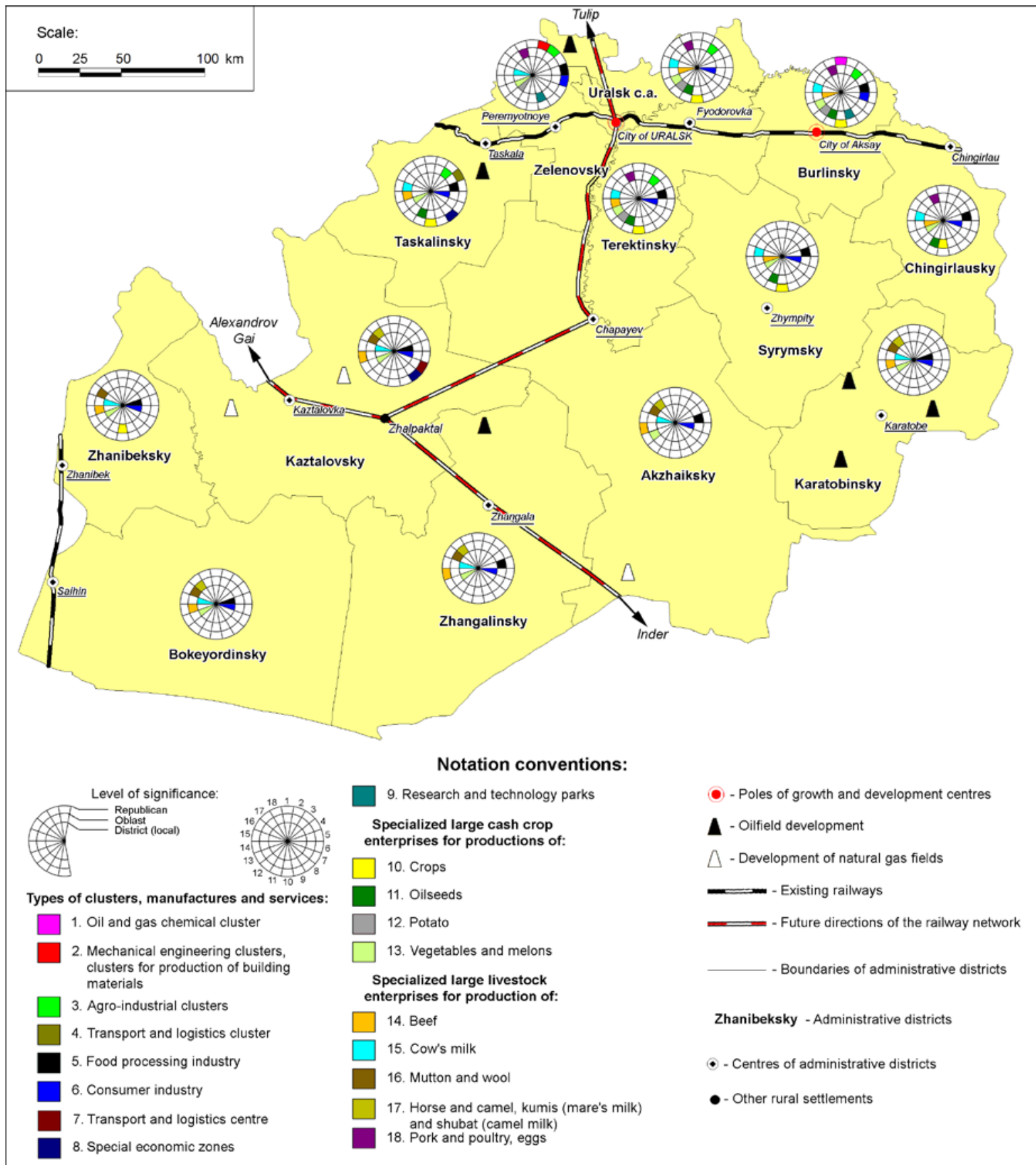

Source: Authors

Thus, the direction of the aforementioned intra-regional policy concerning regulation of spatial asymmetry of the West Kazakhstan region social and economic development may become more 
effective for administrative districts located to the south, east, west, and southwest of the region. This will increase the pace of social and economic development and reduce the existing contrasts in the quality of life of the population. In the medium term, the main objective of intra-regional policy of the West Kazakhstan region administration is to reduce the population outflow from these administrative districts, which are lagging behind the northern territories in the pace and level of development.

\section{Conclusion}

The current polarization in the allocation of the population and productive forces has led to spatial asymmetry in the level of social and economic development of the West Kazakhstan region administrative districts. The typology of the West Kazakhstan region administrative districts shows that low levels of social and economic development are a characteristic of the administrative districts located to the south, west, east, and southwest of the region. They lag behind the northern administrative districts in both level and pace of development, which determines the need for regulation of spatial development process. For effective territorial organization of the West Kazakhstan region economy and population, the priority in the intra-regional policy should be to accelerate the process of economic development of the lagging administrative areas, and to improve the quality of life for the population. The noted general directions and regulation methods for the spatial asymmetry of the social and economic development can contribute to effective territorial organization of the West Kazakhstan region economy and population.

In this regard, there is a need for territorial and structural transformation and modernization of West Kazakhstan region spatial social and economic development to form a single competitive territorial social and economic system, which is able to improve the quality of life for the population, both in urban and in rural areas.

\section{References}

Department of Statistics of West Kazakhstan region (DOSWKO) (2012). Retrieved from http://www.batys.stat.kz.

Dmitrevsky, Y. D. (1991). Quantitative assessment of regional characteristics. Geography at school, 2 , $24-29$.

Ibragimova, Z. I. (2006). Comprehensive methodology for assessing social and economic development of the regions of the Republic of Kazakhstan. Geography in schools and universities in Kazakhstan, 3, 2-4.

Kozyeva, I. A., \& Kuzbozhev, E. N. (2007). Economic geography and regional studies: Study guide. Moscow: KNORUS.

Regional statistical yearbook of the region (Statistical yearbook) (2002). Uralsk: Statistical Office of West Kazakhstan region.

Results of migration of West Kazakhstan region for 2008 (Statistical Collection) (2009). Uralsk: Department of Statistics of West Kazakhstan region.

Safiullina, R. M., \& Khamadeyeva, Z. A. (2009). Demography: Study guide for students of geographic and social science majors. Ufa: RIC BashSU.

Statistical Abstract (2009). Uralsk: Department of Statistics of West Kazakhstan region.

Statistical yearbook of the region. (2000). Uralsk: Statistical Office of West Kazakhstan region.

Statistical yearbook of the region. (2004). Uralsk: Statistical Office of West Kazakhstan region.

West Kazakhstan: Statistical yearbook of the region (2008). Uralsk: Department of Statistics of West Kazakhstan region.

West Kazakhstan region in the independence years (Anniversary Collection) (2001). Uralsk: Statistical Office of West Kazakhstan region.

Zhydkyh, A. A. (2003). The territorial organization of the regional socio-economic development (for example, Altay territory). An abstract from scientific degree competition of Economy Science. Barnaul. 